continent, where Dumont Durville is made to land. It is a masterly panorama of a number of climes and countries, enlivened by a well-constructed plot.

DR. Hork, of Leyden, sends us the following additions to the list of dealers in zoological specimens given by Prof. Ray Lankester in a recent number of NATURE:-I, Hilmar Lührs, Fischer f. Zoologen und Aquarien, Helgoland (Unterland), for fish and invertebrates (alive and in spirits, specimens of all classes). 2. The Zoological Station of Dr. Anton Dohrn, Naples, for fish and invertebrates (spirit specimens).

Tue additions to the Zoological Society's Gardens during the past week include three Tigers (Felis tigris), born in the Gardens, but did not survive; a Common Genet (Genetta vul garis) from North Africa, presented by Mr. P. V. Carletti ; two Hyacinthine Porphyrios (Porphyrio hyacinthinus) from West Asia, presented by Mrs. Henry Cobb; two All-Green Parakeets (Brotogerys tiriacula) from South America, presented by Miss Kowe; two Yellow-bellied Liothrix (Liothrix luteus) from India, presented by Gen. Breton; two common Marmosets (Hapale jacchus) from South-east Brazil, presented by Mrs. Clayton; three Darwin's Pucras (Pucrasia darwini), a Chinese Blue Magpie (Urocissa sinensis) from China, a Sun Bittern (Eurypyga helias) from South America, deposited; a Moose (Alces mashlis) from North America, purchased.

\section{AMERICAN SCIENCE}

PROF. HENRY'S portion of the report of the Smithsonian Institution for the year 1876 has been printed in separate pamphlet form, in advance of the entire volume, and gives the usual record of operations for the period. It draws attention to the fact that it is the thirtieth of the annual series made by hin, and that the policy advised at the first meeting of the board has been carried out with scarcely any modification. The original fund of $54 \mathrm{I}, 379$ dols. has been increased to $7 \mathrm{r} 4,000$ dols., although a building costing nearly 500,000 dols. has been erected. There is a library of 70,000 volumes of the most valuable class of books, namely, the scrial scientific publications of learned societies. The museum has grown until it now ranks among the best in existence. This embraces copious collections illustrating the ethnology and natural history of the world. The institution has published twenty-one quarto and forty-two octavo volumes of transactions and reports. It has carried on successfully a great system of meteorological observations (only intermitted on the successful operations of the Signal Service) the results of which have been issued by a number of stately volumes. It is now prosecuting a great system of international exchanges, for the benefit of the whole world. Its correspondence, both at home and abroad, requires a large number of clerks and specialists; and the name of Smithson is universally known in consequence.

Details have been recently published (Proc. Acad. Nat. Sci. Philadelphia, $187 \%$, p. 255) of the exploration of a specially interesting mound at Coup's Creek, Macoupin County, Illinois. Four skeletons sat within it, considerably enveloped in a peculiar granulated but exceedingly tenacious earth. They were placed two and two, their arms crossed, the knees of one pair pressing sharply against the backs of the other, and the faces of all turned directly toward the east. Though the greatest care was taken, only one skull was removed comparatively perfect. The whole grave measured but six feet in length by three in width, and it contained in addition to the skeletons four large marine shells of Iyrula (Busycon) perversa (Luin.), each similarly placed in rela. tion to the bodies. The smaller end of one shell was placed in the right hand of each individual, while the larger portion rested in the hollow above the left hip. But, still more remarkable, within each shell had been packed what appeared to be the bones of a child; the skull, crushed before burial, protruded beyond the aperture. The suggestion is made that these infants were sacrificial offerings in honour of the dead. The graves in these mounds are constructed of stone slabs from the locality, and hence they are known as stone graves. The builders give evidence of decided constructive ability, and of having been careful cultivators of the soil. The grave-mounds are found upon ridges, while others on which dwellings were supported are near streams. A systematic series of mounds of similar origin extends from the foot of Lake Michigan to the mouth of the Illinois river, a distance of two hundred and fifty miles. Unfortunately the remains are scarcely ever capable of being prese:ved, or even of being examined satisfactorily on exhumation.

The following are notes of papers in the October num. ber of the American Foumal of Science and Arts:-The nickel plates now largely used as anodes for nickel plating are prepared by fusing commercial nickel, generally with addition of charcoal, and casting in suitable form. From an analysis of several specimens of cast nickel by Mr. Gard, it appears that silica may be reduced and retained as silicon, and that a considerable amount of carbon may be present (e.g., I.9 and $\mathrm{x} \cdot 8$ per cent.). One experiment made with a view to ascertain how much carbon nickel may take up under conditions to which it is more or less exposed in the processes of manufacture and casting, was to pack half-a-pound of granular commercial nickel in layers with charcoal in a Hessian crucible, in which it was exposed to a full red-heat twelve hours. No fusion took place. The temperature was then raised till there was com. Flete fusion. The resulting metal was strongly magnetic, quite soft, and to a considerable extent malleable. Its specific gravity was 8.04 , and it had a fracture like that of fine-grained pig-iron, scales of graphite being plainly visible. It was found to contain of total carbon $2 \cdot 105,2 \cdot 130$; graphitic carbon, 2,030, I'990; silicon, 36o. Mr. Gard also made some experiments on the deportment of nickel and cobalt towards hydrocarbon at a high temperature, the substances being placed in a platinum trough within a porcelain tube and treated with a slow current of pure dry marsh-gas at a full red heat. In one.case thin plates of pure electroplate nickel $(.8597 \mathrm{gr}$.) were found at the close to have gained 10.649 per cent.; in another $x^{*} \cdot 2697 \mathrm{gr}$. of cobalt gained $1275^{8}$ per cent.

Among other chemical contributions we note one on the iodates of cobalt and nickel, by Mr. Fullarton, who finds that the true normal iodates contain really six molecules of water of crystallisation, and that they are essentially different fro:n the salts obtained by Rammelsberg. Several specific-gravity determinations follow (by students of Cincinnati University?, including those of a series of chromates, by Miss Abbot. Pettersson has lately shown that selenates have molecular volumes exceeding those of the corresponding sulphates by six for each molecule of the acid radicle. On comparing the chromates with Pettersson's selenates, it is found that the two series of salts have approximateiy equal molecular volumes; the difference, if any exists, being very slightly plus for the selenates. If regularities of this kind can be thoroughily established, it will be easy (Prof. Clark suggests), having the density of a chromate, to calculate that of the corresponding sulphate or selenate, or vice versâ.

A preliminary catalogue of the reptiles, fishes, and Leptocardians of the Bermudas is furnished by $\mathrm{Mr}$. Brown Goode, comprising $\mathrm{x} 48$ out of $\mathrm{I} 63$ known species. The Bermudan fauna shares with the West Indies II 6 species (or 79 per cent.), of which $5^{8}$ (or 40 per cent.) are peculiar to the West Indies, while many others have their centres of distribution in that region. With the Eastern United States Bermuda shares 47 species, and with the waters of the Pacific and Indian Ocean 32 species. $\mathrm{Mr}$. Goode also gives a description of four species of fishes believed to be new.

Prof. Dana draws some lithological and orographic conclu. sions in his (continued) paper on the relations of the geology of Vermont to that of Berkshire, and the Joumal also contains some information on the Archeean of Canada and the geology of New Hampshire, \&c.

\section{THE EARTHWORM IN RELATION TO THE FERTILITY OF THE GROUND}

FROM observations extending overa number of years, $M$. Hensen is led to the conclusion that infertile undersoil is rendered valuable by the action of worms in two ways, viz., by the opening of passages for the roots into the deeper parts, and by the lining of these passages with humus. This will be more fully understood from the following facts regarding the life-habits of the worm (Lumbricus teriestris) given in M. Hensen's paper in the Zeitschrift für wissenschaftliche Zoologie.

It is known that the adult animals in wet weather come up to the surface by night, and, with their hinder end in their tube, 
searcli the ground round about. They then draw whatever vegetable material they can find into their tubes--fallen stems and leaves and small branches. In the morning one then finds little heaps of plant-fragments projecting at various parts of the surface, and each of them penetrating the tube of a worm. On closer examination it is found that the leaves have each been rolled together by the worm, and then drawn into the tube in such a way that the leaf-stalk projects. The portion of the leaf in the tube is moist and softened, and only in this state are plants consumed by the worm. There are distinct indications that the worm gnaws them, and after some days the meal is ended. The food is never drawn deeper down into the ground. In digging the ground at various seasons it was only very rarely that plant remains were found in the subsoil, and probably they got there by accident.

With reference to the structure of the worm-tubes, some interesting facts were established in these researches. In humus their character is difficult to make out, owing to the looseness of the mass. In sand they proceed almost vertically downwards three, four, or even six feet, whereupon they often extend some distance horizontally ; more frequently, however, they terminate without bending. At the end of the tube the worm is found with his head upwards, while round about him the tube is lined with small stones. On the sandy wall of the tube one observes more or less numerous black protuberances which make the sand fertile. These are the secretions of the worm, which, after being removed out of a tenanted tube, are found next morning replaced by fresh matter. They are observed after a few days, when a worm is put in a vessel with clean sand, and allowed to make a tube for itself. Older abandoned tubes are pretty regularly lined with the earth formed by the worm, and some passages are densely filled with black earth. This black substance appears to diffuse somewhat into the sand.

In about half of the tutes, not quite newly made, M. Hensen found roots of the plants growing at the surface, in the most vigorous development, running to the end of the tube and giving off fine root-hairs to the walls, especially beautiful in the case of lcafy vegetables and corn. Indeed such tubes must be very favourable to the growth of the roots. Once a root-fibre has reached such a tube it can, following the direction of gravity, grow on in the moist air of the passage, without meeting with the least resistance, and it finds moist, loose, fertile earth in abundance.

The question whether all roots found in the under-soil have oxiginally grown in the tubes of worms, cannot be answered with certainty. It is certain that the roots of some plants penetrate themselves in the sand, but not to great depths. M. Hensen is of opinion that the tap-roots, and in general such root-forms as grow with a thick point, can force a path for themselves, while the fine and flexible suction-roots have difficulty in obtaining a path into the depths other than what has been previously made for them. Roots of one year's growth especially can penetrate deep into the sub-soil, only where there are earth-worms.

A microscopical comparison of the earth deposited by the worm shows that it is like the two-year leaf-mould prepared by gardeners for the filling of flower-pots. Most of the plant-cells are destroyed; still there are present some cells and shreds of tissue, browned and friable, mixed with many sand grains and brown organic fragments. The chemical composition of the worm-earth shows much similarity to that of fertile humus ground. Its fertility, therefore, cannot be doubted, though direct experiments with it are wanting.

With regard to the numerical value of this action of the earthworm, the following observations by M. Hensen afford some information.

Two worms were put into a glass pot $\mathrm{I}_{\frac{1}{2}}$ foot in diameter, which was filled with sand to the height of $I_{2} \frac{1}{2}$ foot, and the surface covered with a layer of fallen leaves. The worms were quickly at work, and after $1 \frac{1}{2}$ month many leaves were down 3 inches deep into the tubes; the surface was completely covered with humus $I \mathrm{~cm}$. in height, and in the sand were numerous worm-tubes partly fresh, partly with a humus wall $3 \mathrm{~mm}$. thick, partly quite filled with humus.

Counting, when an opportunity offered, the open worm-tubes in his garden, M. Hensen found at least nine in the square foot. In 0.15 square metres two or three worms were found in the deeper parts each weighing three grammes: thus in the hectare there would be 133,000 worms with 400 kilos. weight. The weight of the secretions of a worm in twenty-four hours was 0.5 grammes. While these numbers are valid only for the locality referred to, they yet give an idea of the action of this worm in all places where it occurs.

The assertion that the earthworms gnaw roots is not proved by any fact ; roots gnawed by worms were never met with, and the contents of the intestine of the worms never included fresh pieces of plants. The experience of gardeners that the earthworm injures pot plants may be based on the uncovering or mechanical tearing of the roots.

"Let us take a retrospective glance," concludes the author, "over the action of tha worm in relation to the fertility of the ground. It is clear that no new manure material can be produced by it, but it utilises that which is present in various ways. I. It tends to effect a regular distribution of the natural manure material of fields, inasmuch as it removes leaves and loose plants from the force of the wind and fixes them. 2. It accelerates the transformation of this material. 3. It distributes it through the ground. 4. It opens up the undersoil for the plant roots. 5. It makes this fertile.

\section{UNIVERSITY AND EDUCATIONAL INTELLIGENCE}

OXFORD.-The University Commissioners are at present occupied in taking evidence on the subject of University requirements. The Dean of Christ Church, the Master of Balliol, the Master of University, the Librarian of the Bodleian, Profs. Clifton, Bonamy Price, Bartholomew Price, Stubbs, and others have appeared, or are to appear during the present week, before the Commissioners,

Mr. Lazarus Fletcher, B.A., of Balliol, has been elected to the vacant Fellowship at University College. Mr. Fletcher obtained a first class in the School of Mathematics in 1875 , a first class in that of Natural Science in 1876 , and the senior mathematical scholarship in 1876 .

It is proposed to found a high school for the City of Oxford, the mayor, aldermen, and citizens having long felt it a reproach that, being the site of one of the most ancient and famous of the Universities of Europe, it has been absolutely without any recognised grammar school available for the sons of the citizens.

London.-Prof. W. K. Clifford, F.R.S., is at present delivering at University College a very interesting course of Lectures on Quateriions. The main object of the course is to bring the physical applications of quaternions as much as possible within the reach of mathematicians of moderate attainments.

A requisition is in course of signature to the chairman of Convocation of London University, Dr. Storrar, asking that an extraordinary meeting of that body may be convened for the purpose of considering and discussing the following resolutione, and for deciding with reference thereto in such manner as to Convocation may seem fit:- "That it being manifestly inexpedient that frequent application should be made to the Crown for new and additional charters, it is desirable that provision should be made in any such charter for all changes in the constitution of the University, either at the time urgent or likely to be soon required; and that it being probable that initiative measures will be shortly taken towards procuring such a new oi additional charter, the following proposals require the serious consideration of Convocation and the Senate :- '(I) An enlargement of the powers directly exercised by Convocation; (2) An increase in the proportion of senators to be nominated or elected by Convocation, and the limitation of the tenure of office in the case of all senators to a term of years ; (3) The encouragement of mature study and original research among the members of the University, by the establishment of University lectureships, of limited tenure, in different departments of learning and science ; (4) The introduction into the constitution of the University of such modifications as may remove all reasonable ground of complaint, on the part of any of the affiliated colleges, with respect to the absence of means for expressing opinion and giving advice to the Senate on the examination regulations, and on the changes proposed to be made therein from time to time. And that a Special Committee of ten members of Convocation be appointed to consider the above-mentioned proposals, and to report thereon to Convocation as speedily as possible." "

The Entrance Science Scholarships in St. Thomas's Hospital have been awarded this year as follows :-The Scholarship of $60 l$. to Mr. Wansborough Jones, B.A. Oxon., and B.Sc., London; and that of $40 l$. to Mr. A. E. Wells. 